\title{
THE QUANTUM-CHEMICAL AND SPECTRAL CRITERIA FOR HYDROGEN BONDING EFFICIENCY IN STRUCTURAL ANALYSIS OF ARAMIDES
}

\author{
Andrey Tokar ${ }^{1,}$, Olga Chigvintseva ${ }^{1}$
}

https://doi.org/10.23939/chcht15.01.009

\begin{abstract}
Some features of hydrogen bonding effects for the phenylon polymer matrix filled with a terlon fiber have been investigated at ab initio approximation. The results of calculations for isolated and dimerized structural forms of $N$-phenylbenzamide as a model compound are in good agreement with the spectral data for this composite material building.
\end{abstract}

Keywords: $a b$ initio calculation, density functional method, topological analysis, atoms-in-molecules theory, natural bond orbital, harmonic vibration frequency.

\section{Introduction}

The single-purpose aromatic polyamide construction materials usually include $\mathrm{C} 1, \mathrm{C} 2$ or phenylon $\mathrm{P}$ systems with some linear heterochain copolymer matrix. In this case the main macromolecule sequence consists of amido groups separated from each other by means of aryl fragments [1]:

$$
\left[-\mathrm{NHC}_{6} \mathrm{H}_{4} \mathrm{NHCOC}_{6} \mathrm{H}_{4} \mathrm{CO}-\right]_{\mathrm{n}}
$$

Aramides are obtained by emulsion polycondensation of meta-phenylenediamine with iso- and terephthaloyl chloride mixture taken in different molar ratios of reagents - from $(3: 1)$ for $\mathrm{C} 1$ to $(3: 2)$ for $\mathrm{C} 2$, respectively. In the case of phenylon $\mathrm{P}$ usually deals with the pure meta-phenylene-iso-phthalamide. Some features of these structures with the high level physicomechanical and thermophysical properties are in Table 1. They are widely used in production of super strong construction and electro isolated plastics for automobile industry including those filled with heat-resisting fibers $[2,3]$.

That is why, the main purpose of this work is to make a detailed structural analysis of polymer binding for the phenylon model system with terlon fiber and the composite material based on it using ab initio methods of

\footnotetext{
${ }^{1}$ Dnipro State University of Agriculture and Economics,

25, S. Yefremov St., 49600 Dnipro, Ukraine

atokar_2004@ukr.net

(c) Tokar A., Chigvintseva O., 2021
}

quantum chemistry as well as some theoretical groundings for hydrogen bonding effects with regard to position and nature of signals in vibrational spectra.

\section{Experimental}

Phenylon infrared spectra were recorded by means of SPECTRUM ONE (PerkinElmer) instrument. The samples for recording were compressed from the pure polymer powder as well as from the composite material based on it including $15 \mathrm{wt} \%$ of terlon fiber according to the standard procedure with $\mathrm{KBr}$ [4]. The effective diameter of the pellets was about $12 \mathrm{~mm}$ with a thickness of nearly $1 \mathrm{~mm}$. In this case not more than $3 \mathrm{wt} \%$ of polymer powder in the pills was appropriate. The high level $a b$ initio quantum-chemical calculations were performed using Gaussian 03, Revision E.01 with the following results visualization in GaussView 3.0 [5]. Some statistical processing of data was carried out using a software package ORIGIN Professional 6.0.

The interaction energy after correcting the basis set superposition error by the counterpoise procedure has been calculated with the full complex basis set by setting the appropriate charge to zero which is located at the same intermolecular configuration as in the complex with similar to other. A topological analysis was performed to calculate the charge density $(\rho)$ and its second derivative Laplacian of charge density $\left(\nabla^{2} \rho\right)$ for bonds of model compounds using the AIM2000 package of programs. The effects of conjugative and hyper conjugative interactions were analyzed using the Natural Bond Orbitals theory (NBO). For each donor NBO $(i)$ and acceptor NBO $(j)$ the stabilization energy $E(2)$ associated with delocalization $(i \rightarrow j)$ is estimated as:

$$
E(2)=\Delta E_{i j}=q_{i} \frac{F(i, j)^{2}}{\varepsilon_{j}-\varepsilon_{i}}
$$

where $q_{i}$ is the donor orbital occupancy, $\varepsilon_{j}$ and $\varepsilon_{i}$ are the diagonal elements (orbital energies), and $F(i, j)$ is the offdiagonal NBO Fock matrix element. 
Some physicomechanical and thermophysical properties of the phenylons

\begin{tabular}{|c|c|c|c|}
\hline Parameter & C1 & C2 & P \\
\hline Density, $\mathrm{kg} / \mathrm{m}^{3}$ & 1330 & 1330 & 1330 \\
\hline Tensile strength, $\mathrm{MPa}$ & $110-120$ & $120-140$ & $100-120$ \\
\hline Flexural strength, MPa & $150-170$ & $220-240$ & $130-150$ \\
\hline Compressive stress at yield point, $\mathrm{MPa}$ & $220-230$ & $210-230$ & $210-230$ \\
\hline Impact strength, $\mathrm{kJ} / \mathrm{m}^{2}$ & $30-40$ & $40-50$ & $20-30$ \\
\hline Hardness, $\mathrm{MPa}$ & 280 & 290 & 300 \\
\hline Vick heat resistance, $\mathrm{deg}$ & 275 & 290 & 270 \\
\hline
\end{tabular}

\section{Results and Discussion}

At the first stages of our investigation, by means of the density functional method in B3LYP/6-311++G(d,p) approach we have studied some features of equilibrium state for unsubstituted $N$-phenylbenzamide (1) [6] that could create the alternative imide forms $(\mathbf{2} \mathbf{a}, \mathbf{b})$ showing construction features of basic structural fragments of phenylon monomeric chain. First of all, such model compound choice could be explained with regard to simplicity and convenience of their following use to study internal and intermolecular interaction being present in these systems. While evaluating species of structure relative energies, specified corrections for zero-point energy calculated within the same theoretical approximation were taken into account. Except reviewing the geometric and energetic molecular parameters, the comparison analysis of features for NBO atomic charges distribution and Wiberg bonding index allowing to conduct an additional evaluation of conjugative and especialy hyper conjugative effects are of some interest too. The results of calculations are shown below (Fig. 1).

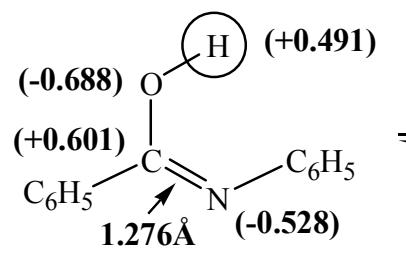

2a

$48.1 \mathrm{~kJ} / \mathrm{mol}$
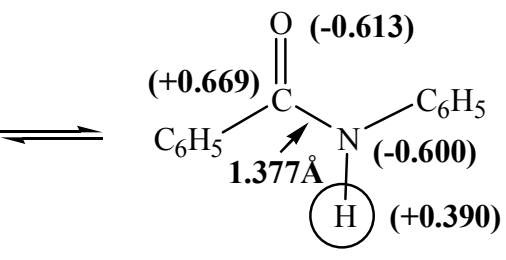

1

$0.0 \mathrm{~kJ} / \mathrm{mol}$<smiles>CN(c1ccccc1)C(C)(Oc1ccccc1)c1ccccc1</smiles>

2b

$65.7 \mathrm{~kJ} / \mathrm{mol}$

Fig. 1. The structures of model compounds with some NBO atomic charges, bond lengths and relative energies

Table 2

Stabilization energies $E(2)$ for orbital interactions in molecule (1) with some geometric parameters

\begin{tabular}{|c|c|c|c|c|}
\hline \multirow{2}{*}{ Orbital interaction character } & \multirow{2}{*}{$E(2), \mathrm{kJ} / \mathrm{mol}$} & \multicolumn{2}{|c|}{ Angles, deg } & \multirow{2}{*}{ Structural fragment } \\
\hline & & Valent & Torsion & \\
\hline $\mathrm{n}(\mathrm{N}) \rightarrow \pi^{*}(\mathrm{C}=\mathrm{O})$ & 218.6 & \multirow{2}{*}{123.8} & \multirow{2}{*}{-} & \multirow{2}{*}{$-\mathrm{NHCO}-$} \\
\hline $\mathrm{n}(\mathrm{O}) \rightarrow \sigma^{*}(\mathrm{C}-\mathrm{N})$ & 107.1 & & & \\
\hline $\mathrm{n}(\mathrm{N}) \rightarrow \pi^{*}(\mathrm{C}=\mathrm{C})$ & 138.9 & 123.5 & - & $-\mathrm{NHC}_{6} \mathrm{H}_{5}$ \\
\hline $\mathrm{n}(\mathrm{O}) \rightarrow \sigma^{*}(\mathrm{C}-\mathrm{C})$ & 77.4 & 121.4 & - & $-\mathrm{COC}_{6} \mathrm{H}_{5}$ \\
\hline$\pi(\mathrm{C}=\mathrm{C}) \rightarrow \pi^{*}(\mathrm{C}=\mathrm{O})$ & 66.4 & \multirow{2}{*}{-} & \multirow{2}{*}{152.3} & \multirow{2}{*}{$-\mathrm{COC}_{6} \mathrm{H}_{5}$} \\
\hline$\pi(\mathrm{C}=\mathrm{O}) \rightarrow \pi^{*}(\mathrm{C}=\mathrm{C})$ & 14.6 & & & \\
\hline$\sigma(\mathrm{NH}) \rightarrow \sigma^{*}(\mathrm{C}-\mathrm{O})$ & 17.7 & \multirow{2}{*}{-} & \multirow{2}{*}{172.2} & \multirow{2}{*}{$-\mathrm{NHCO}-$} \\
\hline$\sigma(\mathrm{C}-\mathrm{O}) \rightarrow \sigma^{*}(\mathrm{NH})$ & 4.5 & & & \\
\hline$\sigma(\mathrm{NH}) \rightarrow \sigma^{*}(\mathrm{C}-\mathrm{C})$ & 16.2 & \multirow{2}{*}{-} & \multirow{2}{*}{180.0} & \multirow{2}{*}{$-\mathrm{NHC}_{6} \mathrm{H}_{5}$} \\
\hline$\sigma(\mathrm{C}-\mathrm{C}) \rightarrow \sigma^{*}(\mathrm{NH})$ & 8.3 & & & \\
\hline
\end{tabular}

The most stable structure (1) was mostly due to the effective binding of the bridge amide group with aryl fragments being nearly close. Wiberg indexes for binding of $(\mathrm{C}=\mathrm{N})$ compounds $(\mathbf{2} \mathbf{a}, \mathbf{b})$ are 1.714 and 1.717 respec- 
tively, while for binding of $(\mathrm{C}-\mathrm{N})$ compound (1) is only 1.137. Stabilization energy parameters $E(2)$ [7] could also be considered as measurement means of effective intermolecular binding as they allow specifying some contributions of single orbital interactions. As shown in Table 2, from this point of view the most important interactions are those of lone electron pairs of Nitrogen and Oxygen atoms of the amide group with the nearest placed bindings of the main molecule chain as well as $\pi$-orbitals of benzene rings. In case of hyper conjugative effects, the contribution into the main stabilization energy is the lowest. That is completely consistent with the generally accepted opinions of such type system structure showing validity of their reproduction within the chosen calculating approximation.

The obtained data spark a huge interest as both separate sections structure elements of phenylon polymer matrix, and their interaction with fiber filling of poly(paraphenyleneterephthalamide) with forming the typical hydrogen bondings $>\mathrm{C}=\mathrm{O} \cdots \mathrm{HN}<$. Based on this assumption, we proposed the theoretical model simulating directly the interaction of $\mathrm{N}$-phenylbenzamide molecules
(1) creating a dimerized form (3). Distribution of the obtained equilibrium dimeric geometry into separate components with their following optimization at B3LYP/6$311++\mathrm{G}(\mathrm{d}, \mathrm{p})$ level of theory resulted in creation of two identical structures. Calculation of vibrational frequencies for all localized saddle points showed no clear deviations allowing to describe them as minima on the potential energy surface. While estimating energetic parameters of the complex (3), specified allowance of the basis set superposition error obtained according to the BoysBernardi procedure [8]. Calculation results are in Fig. 2.

Analysis of the orbital interactions appearing while hydrogen bonding complex formed within the previously used NBO [9] theory has shown that the main contribution to the total energy of the system stabilization are lone electron pairs of Oxigen atom of the group $(\mathrm{C}=\mathrm{O})$ serving as a donor of the electron density to bind partner molecule $(\mathrm{NH})$. Corresponded parameters $E(2)$ for $\mathrm{n}_{1,2}(\mathrm{O}) \rightarrow \sigma^{*}(\mathrm{NH})$ bridging are 15.4 and $9.5 \mathrm{~kJ} / \mathrm{mol}$ (Table 3), when other internal and intermolecular interactions slightly differ in energy and mostly have the electrostatic character.

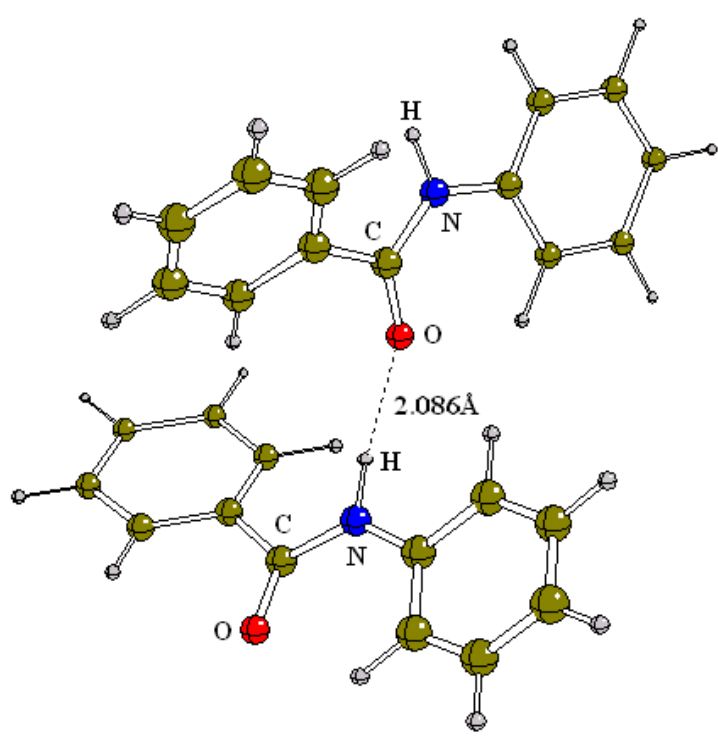

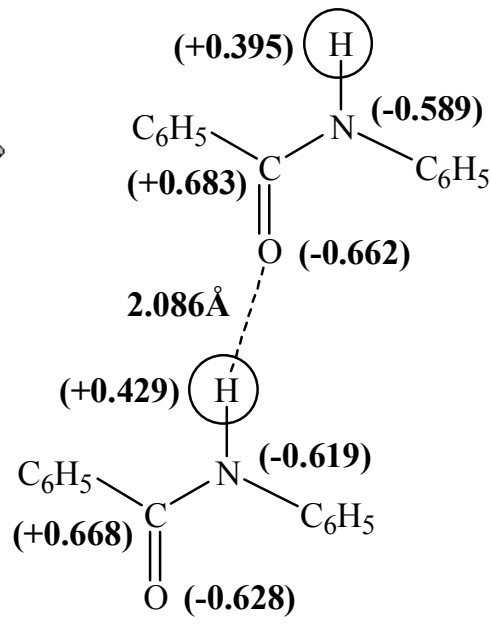

3

$17.8 \mathrm{~kJ} / \mathrm{mol}$

Fig. 2. Theoretical model of hydrogen bonding complex with some geometric, energetic and charge density characteristics of the system

Table 3

Stabilization energies $E(2)$ for orbital interactions in dimer (3)

\begin{tabular}{|c|c|c|c|}
\hline Orbital interaction character & $E(2), \mathrm{kJ} / \mathrm{mol}$ & Orbital interaction character & $E(2), \mathrm{kJ} / \mathrm{mol}$ \\
\hline $\mathrm{n}_{1}(\mathrm{O}) \rightarrow \sigma^{*}(\mathrm{NH})$ & 15.4 & $\mathrm{n}_{3}(\mathrm{O}) \rightarrow \sigma^{*}(\mathrm{CH}-$ ortho $)$ & 2.7 \\
\hline $\mathrm{n}_{2}(\mathrm{O}) \rightarrow \sigma^{*}(\mathrm{NH})$ & 9.5 & $\mathrm{n}_{4}(\mathrm{O}) \rightarrow \sigma^{*}(\mathrm{CH}-$ ortho $)$ & 1.0 \\
\hline $\mathrm{n}_{1}(\mathrm{O}) \rightarrow \sigma^{*}(\mathrm{CH}$-ortho $)$ & 4.9 & $\pi(\mathrm{C}=\mathrm{O}) \rightarrow \sigma^{*}(\mathrm{CH}$-ortho $)$ & 1.6 \\
\hline $\mathrm{n}_{2}(\mathrm{O}) \rightarrow \sigma^{*}(\mathrm{CH}$-ortho $)$ & 3.4 & $\pi(\mathrm{C}=\mathrm{C}) \rightarrow \sigma^{*}(\mathrm{CH}$-ortho $)$ & 1.6 \\
\hline
\end{tabular}


Table 4

Some values of topological parameters in $(3,-1)$ critical points of bindings depending on their lengths

\begin{tabular}{|c|c|c|c|c|c|}
\hline Parameter & \multicolumn{5}{|c|}{$D F T-\mathrm{B} 3 \mathrm{LYP} / 6-311++\mathrm{G}(\mathrm{d}, \mathrm{p})$} \\
\hline$\rho, \mathrm{e} / \AA^{3}$ & 0.0187 & 0.0170 & 0.0083 & 0.0076 & 0.0042 \\
\hline$-\nabla^{2} \rho, \mathrm{e} / \AA^{5}$ & 0.0174 & 0.0156 & 0.0068 & 0.0067 & 0.0028 \\
\hline$r, \AA$ & 2.193 & 2.246 & 2.523 & 2.600 & 2.997 \\
\hline
\end{tabular}

To identify nature of such bindings within the atoms-in-molecules (AIM) Bader's theory [10], we calculated values of electron density as well as Laplacian of electron density in $(3,-1)$ critical points of the least energy intensive interactions in order to evaluate them additionally with regard to their binding efficiency. As shown in Table 4, the obtained topological parameters are well correlated with the lengths of the corresponding bindings within the whole range of given values. Fig. 3 also showed $\rho(r)$ and $-\nabla^{2} \rho(r)$ pick relations, pointing at clear bending with the division of strength-middle hydrogen bindings and weak Van der Waals interactions at distances of about $2.500 \AA$.

The received data fully correspond to the literary one [11] describing features of electron density division in molecular crystals of aromatic structures with regard to effective stacking-interactions [12, 13] and thus can be used for identification of the single bindings character within one its type. It should be noted that the electron density Laplacian as an efficiency criteria of such binding is less fitting to be used [14]:

$$
\begin{gathered}
\rho(r)=(0.0028 \pm 0.0009)+ \\
+(0.0162 \pm 0.0009) \cdot \exp [(2.193-r) /(0.325 \pm 0.047)] \\
-\nabla^{2} \rho(r)=(0.0163 \pm 0.0013) \cdot \exp [(2.193- \\
-r) /(0.335 \pm 0.067)]
\end{gathered}
$$

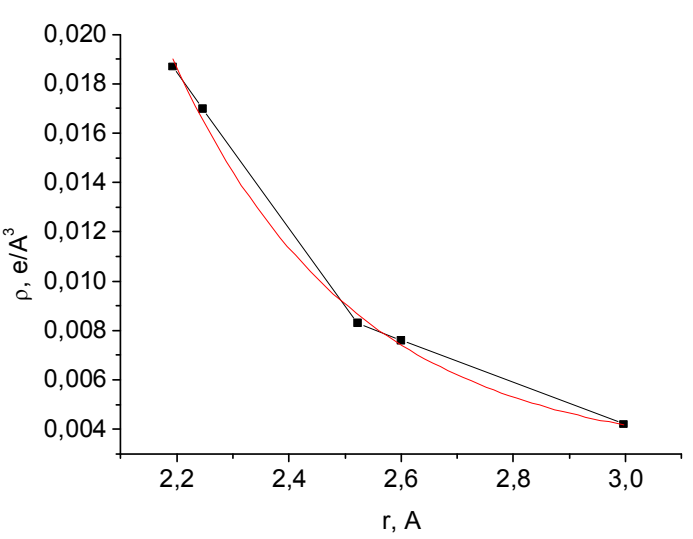

a)
Correlation equations based on these properties allow the interaction energy between benzene rings to be predicted with the minimum mean relative error in the energy for the given region of the potential energy surface.

To prove the crucial role of the hydrogen bonding effects in the phenylon structure we performed the detailed analysis of vibrational spectra of the above described isolated (1) and dimerized (3) forms to their following comparison with each other as well as with experimental data. It should be noted, that the last theoretical model properly shows in full the structure situation according to which the interacting molecules also includes unbonded analogs together with the $(>\mathrm{C}=\mathrm{O})$ and $(>\mathrm{NH})$ bonded by hydrogen atom groups. As known, the harmonic vibrational frequencies calculated by means of quantum-chemical methods are usually more than their analog parameters achieved experimentally. In the author's opinion [15], the main source of faults is ignoring the anharmonicity effects as well as the lack of full description of electron correlations constrained with the use of the limited sets of basis functions. To increase data calculation accuracy in their simulation of the main spectral characteristics of observed system, we used some additional values of the scale factors being 0.9580 and 0.9688 for the $6-311+\mathrm{G}(\mathrm{d})$ and $6-311+\mathrm{G}(\mathrm{d}, \mathrm{p})$ basis sets accordingly in case of the triparametric hybrid functional B3LYP [15]. The obtained data are shown in Table 5 and Fig. 4.

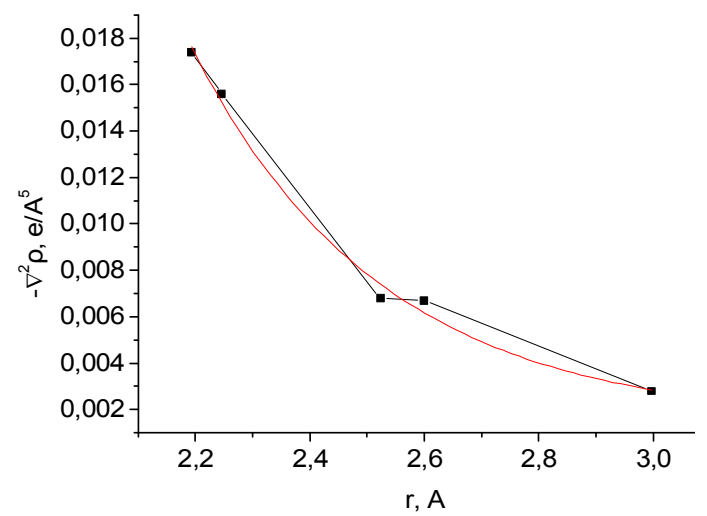

b)

Fig. 3. The characteristic curves of electron density (a) and Laplacian of electron density (b) as an interatomic distances function 
The Quantum-Chemical and Spectral Criteria for Hydrogen Bonding Efficiency in Structural Analysis... 13

Table 5

Harmonic vibrational frequencies $\left(\mathrm{cm}^{-1}\right)$ obtained experimentally as well as calculated in approximation $D F T-B 3 L Y P / 6-311++G(d, p)$

\begin{tabular}{|c|c|c|c|c|c|c|c|}
\hline \multirow{2}{*}{$\begin{array}{l}\text { Intensity, } \\
\text { band shape }\end{array}$} & \multicolumn{4}{|c|}{ Experimental data } & \multicolumn{2}{|c|}{ Calculation results } & \multirow{2}{*}{ Interpretation } \\
\hline & $\mathrm{C} 1$ & $\mathrm{C} 2$ & $\mathrm{P}$ & C1T15 & Model (1) & Model (3) & \\
\hline \multirow[b]{2}{*}{ v.w., wd. } & 3405 & 3410 & 3400 & 3414 & - & - & capacity of moisture \\
\hline & $\begin{array}{l}3267 \\
3069\end{array}$ & $\begin{array}{l}3276 \\
3069\end{array}$ & $\begin{array}{l}3290 \\
3060\end{array}$ & $\begin{array}{l}3284 \\
3069\end{array}$ & 3510 & $\begin{array}{l}3504 \\
3399\end{array}$ & $v_{(\mathrm{NH})}$ of amido groups \\
\hline \multirow{2}{*}{ v.w. } & 2921 & 2917 & 2912 & 2912 & 3092 & 3094 & \multirow{2}{*}{$v_{(\mathrm{CH})}$ of benzene rings } \\
\hline & 2851 & 2851 & 2843 & 2851 & 3051 & 3070 & \\
\hline s. & 1649 & 1654 & 1647 & 1658 & 1677 & 1658 & $v_{(\mathrm{CO})}$ of amido groups \\
\hline \multirow{3}{*}{ v.s. } & 1605 & 1605 & 1598 & 1605 & 1591 & 1589 & \multirow{3}{*}{$\begin{array}{c}v_{(\mathrm{CC})} \text { of benzene rings with } \delta_{(\mathrm{NH})} \\
\text { of amido groups }\end{array}$} \\
\hline & 1526 & 1531 & 1529 & 1535 & 1582 & 1530 & \\
\hline & 1474 & 1478 & 1471 & 1482 & 1568 & 1511 & \\
\hline \multirow{3}{*}{ s. } & 1412 & 1412 & 1402 & 1412 & 1478 & 1480 & \multirow{2}{*}{$\delta_{(\mathrm{CH})}$ of benzene rings } \\
\hline & 1307 & 1307 & 1294 & 1307 & 1419 & 1420 & \\
\hline & 1237 & 1237 & 1225 & 1237 & 1298 & 1301 & $v_{(\mathrm{CN})}$ with $\delta_{(\mathrm{CH})}$ of benzene rings \\
\hline \multirow{2}{*}{ av. } & 860 & 860 & 814 & 860 & \multirow{2}{*}{ - } & \multirow[b]{2}{*}{-} & \multirow[t]{2}{*}{ (l) } \\
\hline & 781 & 785 & 765 & 789 & & & \\
\hline \multirow{2}{*}{ w. } & 719 & 724 & 716 & 728 & 745 & 745 & \multirow{2}{*}{ capacity of $\delta_{(\mathrm{CH})}$ for benzene rings } \\
\hline & 684 & 684 & 667 & 684 & 696 & 692 & \\
\hline v.w. & 570 & 570 & 569 & 570 & 546 & 574 & $\delta_{(\mathrm{NH})}$ of amido groups \\
\hline
\end{tabular}

Notes: s. - strong, av. - average intensity, w. - weak, wd. - wide, v. - very; $v$ - stretching vibrations, $\delta$ - bending vibrations; $\mathrm{C} 1, \mathrm{C} 2$ and $\mathrm{P}$ - pure phenylon powder, C1T15 - composite material based on phenylon $\mathrm{C} 1 \mathrm{with} 15 \mathrm{wt} \%$ of terlon fiber.

According to the literary data [16, 17], the structural identification of aliphatic polyamides includes reviewing of feature absorption bands with a valid signals assignment in $3280,2900,1640,1550$ and $1545 \mathrm{~cm}^{-1}$ areas. Analysis of the obtained results (Table 5) shows the presence of wide bands at 3284 and $3267 \mathrm{~cm}^{-1}$ corresponding to the stretching vibrations $(\mathrm{NH})$ of amido groups. In the area of $\sim 1650 \mathrm{~cm}^{-1}$ there is the "Amide I" intensive band being common for carbonyl with the main contribution of the hydrogen bonding effects. Indeed, in the case of (1) and (3) calculated structures there is a visible disposition of this absorption band from $1677 \mathrm{~cm}^{-1}$ for the $\left(>\mathrm{C}=\mathrm{O}\right.$ ) "isolated group" to $1649 \mathrm{~cm}^{-1}$ together with the hydrogen bonding. Similar signal disposition $v_{(\mathrm{NH})}$ could be observed from 3510 to $3400 \mathrm{~cm}^{-1}$. Finally, in the area of $\sim 1530 \mathrm{~cm}^{-1}$ there is the "Amide II" visible band corresponding to stretching vibrations of the carboncarbon bindings of aryl fragments with $\delta_{(\mathrm{NH})}$.

The band "Amide III" is observed at nearly $1237 \mathrm{~cm}^{-1}$. Its disposition in the case of terlon to $1265 \mathrm{~cm}^{-1}$ is fully consistent with the influence of intermolecular interactions, which take place in this system. At the same time, an increase in the degree of crystallinity of the sample contributes to the displacement of the band "Amide III" in the area of larger wave numbers. It should be noted that among all the isomeric polyphenylenephthalamides, in the case of terlon fiber the desire for orderliness is expressed to the greatest extent. For a more detailed analysis of the nature of absorption bands in
$1200-500 \mathrm{~cm}^{-1}$, their interpretation, in addition to the generals, also came from the theoretical notions that the replacing, for example, a para-substituted benzene ring with a meta-substituted one should lead to significant changes in the position of the signals, their form, and intensity. Therefore direct comparison of the spectra of isomeric polyamides makes it possible, according to the authors [18], to specify the interpretation of individual absorption bands.

As for the "Amide IV", "Amide V" and "Amide VI" bands, only the absorption in the region $716-728 \mathrm{~cm}^{-1}$ with "Amide V" vibration is clearly established, while the interpretation of two other signals, especially the "Amide VI", needs to be further verified. Indeed, in this area there are numerous bending vibrations of benzene rings, which from this point of view should also be considered as characteristic ones. The following averaged sets of wave numbers, which obtained for the whole range of investigated polymer systems correlate well with each other, showing the adequate reproduction of spectral features of materials within the chosen calculated approximation:

$$
\begin{gathered}
v, \delta(\exp .)=(75.96 \pm 28.34)+(0.90 \pm 0.01) \cdot v, \delta(\mathbf{1}) ; \\
r=0.995 ; S_{0}=47.71 ; n=13 \\
v, \delta(\exp .)=(79.27 \pm 30.46)+(0.91 \pm 0.01) \cdot v, \delta(\mathbf{3}) ; \\
r=0.997 ; S_{0}=53.67 ; n=14
\end{gathered}
$$

where $r$ is the corresponding correlation coefficient, $S_{0}$ is the standard deviation as well as $n$ is a number of set points [19]. 


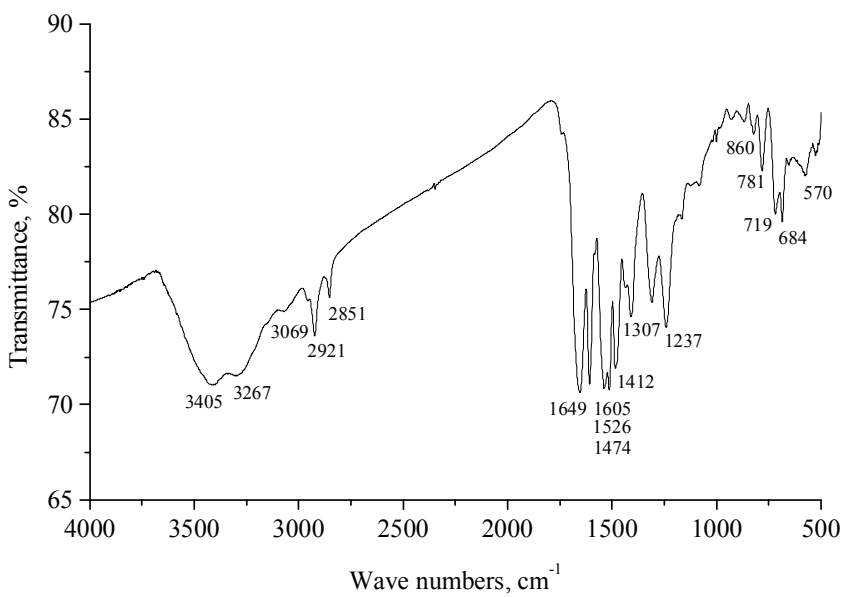

a)

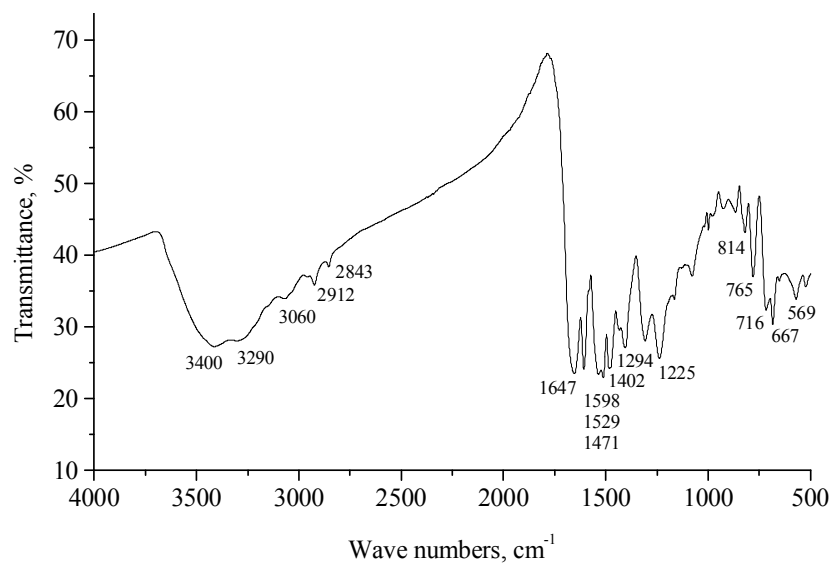

c)

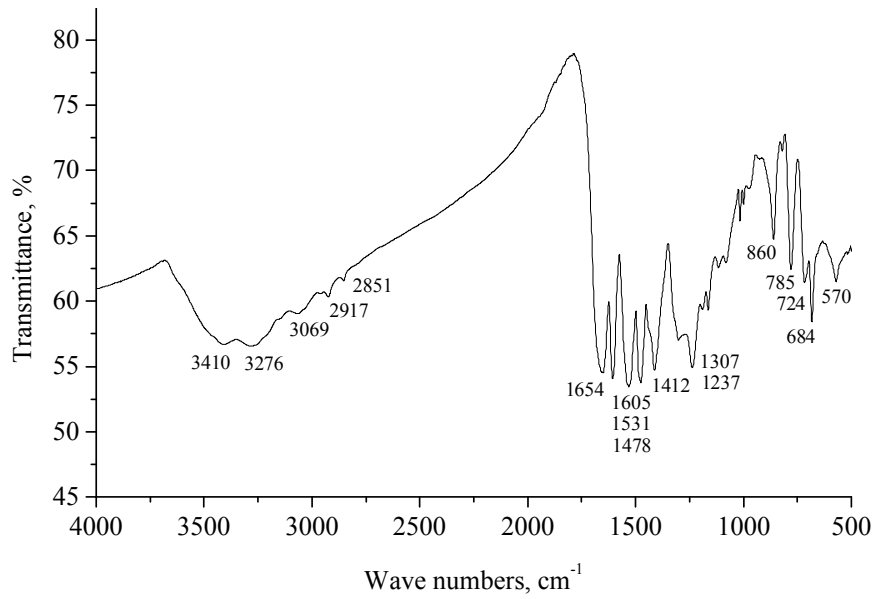

b)

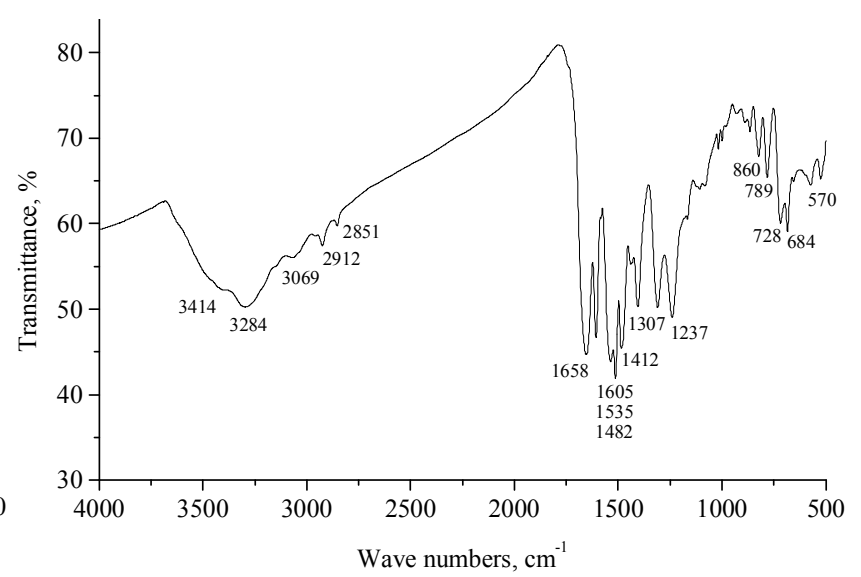

d)

Fig. 4. IR absorption spectra of pure C1 (a), C2 (b), P phenylon (c) and the composite C1T15 (d)

\section{Conclusions}

The given results of the quantum-chemical studies show the principle possibility to use methods and techniques of the quantum chemistry to study features of internal and intermolecular interactions at the single areas level - the structural fragments of macromolecules. Analysis of the orbital interactions appearing while hydrogen bonding complex formed within the NBO theory has shown that the main contribution to the total stabilization energy of the system are the lone pairs of Oxygen atom of the group $(\mathrm{C}=\mathrm{O})$ serving as a donor of the electron density to bind partner molecule $(\mathrm{NH})$. Corresponded parameters $E(2)$ are 15.4 and $9.5 \mathrm{~kJ} / \mathrm{mol}$, when the other internal and intermolecular interactions slightly differ in energy and mostly have the electrostatic character. To identify nature of such bindings within the atoms-in-molecules (AIM) Bader's theory, electron density as well as Laplacian of electron density in $(3,-1)$ critical points of the least energy intensive interactions have also been evaluated. The results of calculations are in good agreement with the spectral data for these polymer materials building and could be critical with regard to the pre-estimation of identity of single components while producing new composite materials based on them.

\section{Acknowledgments}

The autors are grateful to the Ukrainian-American Laboratory of Computational Chemistry (SSI "Institute for Single Crystals" of National Academy of Sciences of Ukraine, Kharkiv) for the great opportunity to carry out this work.

\section{References}

[1] Poly- $m$-fenilenizoftalamid (fenilon). Poly- $p$-fenilentereftalamid [in:] I. Knunyants (Ed.), Khimiya. Bolshoy Entsiklopedicheskiy Slovar. Bolshaya Rossiyskaya Entsiklopediya, Moskva 1998, 468. 
[2] Burya A., Chigvintseva O.: Primenenie Polimernykh Materialov i Kompozitov na ikh Osnove v Avtomobilestroenii. Fedorchenko A.A., Dnepropetrovsk 2010.

[3] Burya A., Naberezhnaya O., Terenin V. et al.: Problemy Tertya ta Znoshuvannya, 2015, 3, 51.

[4] Thompson J.: Infrared Spectroscopy. Jenny Stanford Publishing, Pan Stanford 2018.

[5] Butyirskaya E.: Kompyuternaya Khimiya: Osnovy Teorii i Rabota s Programmami Gaussian i GaussView. SOLON-PRESS, Moskva 2011. [6] Tokar A., Synchuk E., Chigvintseva O.: Chem. Chem. Technol., 2017, 11, 405. https://doi.org/10.23939/chcht11.04.405

[7] Weinhold F., Landis C.: Discovering Chemistry With Natural Bond Orbitals. John Wiley \& Sons, New Jersey 2012.

[8] Sordo J.: J. Mol. Struct., 2001, 537, 245.

https://doi.org/10.1016/S0166-1280(00)00681-3

[9] Weinhold F.: J. Comput. Chem., 2012, 33, 2363.

https://doi.org/10.1002/jcc.23060

[10] Kolandaivel P., Nirmala V.: J. Mol. Struct., 2004, 694, 33. https://doi.org/10.1016/j.molstruc.2004.01.030

[11] Munshi P., Guru Row T.: CrystEngComm., 2005, 7, 608. https://doi.org/10.1039/B511944H

[12] Zhikol O., Shishkin O., Lyssenko K. et al.: J. Chem. Phys., 2005, 122, 144104. https://doi.org/10.1063/1.1877092

[13] Hill J., Platts J., Werner H.: Chem. Phys. Phys. Chem., 2006, 8, 4072. https://doi.org/10.1039/b608623c

[14] Tsirelson V.: Kvantovaya Khimiya. Molekuly, Molekulyarnye Systemy i Tverdye Tela. BINOM. Laboratoriya znaniy, Moskva 2010.
[15] Merrick J., Moran D., Radom L.: J. Phys. Chem. A., 2007, 111, 11683. https://doi.org/10.1021/jp073974n

[16] Vorsina I., Grigoreva T., Vosmerikov S. et al.: Nauka i Studia, 2015, 5, 20.

[17] Lirova B., Rusinova E.: Analiz Polimernykh

Kompozitsionnykh Materialov. Izd-vo Uralskogo Univ., Ekaterinburg 2008.

[18] Redchuk A., Burya A.: Polimerniy Zh., 2011, 33, 128.

[19] http://www.consol.ca/downloads/Statistics_in_Chemistry.pdf

Received: April 16, 2019 / Revised: July 08, 2019 / Accepted: November 21, 2019

\section{КВАНТОВО-ХІМІЧНІ ТА СПЕКТРАЛЬНІ КРИТЕРІЇ ЕФЕКТИВНОСТІ ВОДНЕВОГО ЗВ'ЯЗУВАННЯ У СТРУКТУРНОМУ АНАЛІЗІ АРАМІДІВ}

Анотація. За допомогою аb іпіtio наближення досліджено характерні особливості ефектів водневого зв'язування у полімерній матрииі фенілону, наповненого волокном терлон. Результати розрахунків для ізольованої та димеризованої структурних форм модельної сполуки $N$-фенілбензаміду добре узгоджуються із спектральними даними щодо будови изьго композииійного матеріалу.

Ключові слова: ab initio розрахунок, метод функиіоналу густини, топологічний аналіз, теорія атоми-в-молекулах, натуральна звязуюча орбіталь, частота гармонічного коливання. 